\title{
Detection of hepatitis $C$ virus antibodies with new recombinant antigens: assessment in chronic liver diseases
}

\author{
J.I. Riezu-Boj ${ }^{1}$, D. Parker ${ }^{2}$, M.P. Civeira ${ }^{1}$, D. Phippard ${ }^{2}$, T.P. Corbishley ${ }^{2}$, J. Camps ${ }^{1}$, A. Castilla ${ }^{1}$ \\ and J. Prieto ${ }^{1}$ \\ ${ }^{1}$ Center for Biomedical Research, Department of Internal Medicine. Clinica Unitersitaria and Medical Sthool. Unicersity of Natarra, Pamplona, Spain \\ and ${ }^{2}$ Vellcome Diagnostics, Beckenham, Kent, United Kingdom
}

(Received 6 May 1991)

A new serological assay to detect antibodies against hepatitis $\mathrm{C}$. based on a recombinant protein (BHC10) which incorporates structural and non-structural viral antigens, was tested in 67 healthy subjects and 409 patients $u$ ith various forms of liver disease. Results were compared with the current assay based on the recombinant non-structural viral antigen c100 and with the recently introduced second-generation assay, Ortho2. None of the healthy subjects was positive by any of the assays. In patients with chronic non-A, non-B hepatitis the prevalence of anti-BHC10 was $96.8 \%$, higher than anti-c $100(83.3 \%, p<0.001)$ and similar to Ortho2 $(94.3 \%)$. False-positive results were less frequently; found when $\mathrm{BHClO}$ was used. These findings show that assays incorporating structural and non-structural antigens provide higher sensitivity to detect hepatitis $C$ virus infection and they define an almost exclusive role of hepatitis $C$ virus in the genesis of chronic non-A, non-B hepatitis.

Key words: HCV antibody; Polymerase chain reaction; Chronic hepatitis C; Chronic hepatitis B; Alcoholic liver disease; Primary biliary cirrhosis; Hepatocellular carcinoma

Since 1989 with the discovery of part of the RNA genome of the non-A, non-B hepatitis (NANBH) agent, now known as 'hepatitis $C$ virus' (HCV), an assay for circulating viral antibodies has been available. In this assay a recombinant non-structural protein (cl00) from a chimpanzee $\mathrm{HCV}$ isolate (1) is used. Anti-cl 100 antibodies have been found in $58-84 \%$ of patients with chronic NANBH (1-5). However, HCV sequences have been detected in serum in cases negative for anti-c100 indicating that a higher propertion of NANBH can be $\mathrm{HCV}$ related (6). On the other hand, false-positive results in patients with autoimmune chronic active hepatitis (7), in blood donors $(8,9)$ and in patients with other diseases (10) have been reported. Thus, a secon'-generation assay is required.

We describe results from a serological test to detect anti-HCV antibodies based on a recombinant antigen (BHC10) which incorporates structural and nonstructural viral proteins, where the non-structural moiety does not contain the cl00 region. This novel test showed enhanced sensitivity and specificity in the identification of $\mathrm{HCV}$ infection. The results obtained with newgeneration assays indicate an almost exclusive role of $\mathrm{HCV}$ in the genesis of chronic NANBH and will probably allow a more efficient prevention of posttransfusional hepatitis.

\section{Materials and Methods}

\section{Subjects}

Serum samples, stored ai $-40 \mathrm{C}$, from 409 patients with liver disease and 67 healthy blood donors were analyzed. Twelve blood donors had been followed over a number of years and had never been implicated in any case of post-transfusional hepatitis. They were considered as accredited donors. Patients were divider into four groups:

Correspondence to: Prof. J. Prieto, Centro de Investigaciones Biomédicas, Departamento de Medicina Interna, Facultad de Medicina. L'niversidad de Navarra, 31008-Pamplona, Spain. 


\section{Chronic NANBH}

This group included 156 patients (55 female, mean age 45.6 years, range $12-72$ ) and fulfilled the following criteria: liver biopsy showing chronic persistent or chronic active hepatitis with or without cirrhosis, the presence of raised serum alanine aminotransferase levels for more than 6 months, negative for $\mathrm{HBsAg}$, alcohol consumption less than $50 \mathrm{~g} / \mathrm{day}$, antinuclear antibodies negative or at titre lower than $1 / 100$, absence of potential hepatotoxic drugs, normal levels of ceruloplasmin and $x_{1}$-antitrypsin. None of these patients was receiving or had received antiviral or immunosuppressive therapy. In $54.4 \%$ there was previous exposure to blood products.

\section{Chronic hepatitis $B$}

Serum samples were obtained from 148 HBsAigpositive patients ( 33 female, mean age 39.2 years, range 5-78) with biopsy-proven chronic hepatitis $(6.1 \%$ ch.ronic persistent, $68.9 \%$ chronic active and $25.0 \%$ cirrhosis); $38.5 \%$ of these patients with hepatitis B virus (HBV) infection showed positive serum HBV-DNA [determined by molecular hybridization using a ${ }^{32}$ P-labelled HBVDNA full-length probe (pBR322-HBV) on serum spots blotted on nitrocellulose filters (11)].

\section{Hepatocellular carcinoma}

This group was formed by 27 patients (six female, nean age 65.2 years. range $47-76$ ) five of whom were HBsAg-positive and the other eight showed positive anti-HBs or anti-HBc.

\section{Other liver diseases}

Seventy-eight serum samples from patients with other forms of liver disease ( 34 female, mean age 48.2 years, range 9-73) were tested. This group included: 33 patients with alcoholic liver disease $(9$ steatosis, 11 alcoholic hepatitis and 13 cirrhosis), 26 primary biliary cirrhosis, 10 non-alcoholic steatosis, 4 inactive cryptogenic cirrhosis, 2 idiopathic cholestasis, 2 liver disease associated with ulcerative colitis and 1 congenital hepatic fibrosis. Liver biopsy was performed in all cases. None of them was receiving immunosuppressive therapy.

\section{Serological studies}

The Wellcome NANBH assay is an enzyme-linked immunosorbent assay (ELISA) based on a recombinant viral antigen polypeptide named $\mathrm{BHC} 10$ encompassing polypeptides from both the core region of HCV (c22) and also the greater part of the NS5 region (putative replicase) of the virus (12). ELISA plates (Nunc, Denmark) coated with BHC10 antigen were incubated at $37^{\circ} \mathrm{C}$ for $45 \mathrm{~min}$ with $200 \mu \mathrm{l} /$ well of a $1 / 20$ serum dilution. Two positive and three negative sera were used as controls. In each plate after washing 6 times with Tween-saline $(0.85 \% \mathrm{NaCl}$ and $0.05 \%$ Tween-20), $100 \mu \mathrm{l}$ / well of 1/12000 anti-human horseradish peroxidase conjugate was added and incubated at $37^{\circ} \mathrm{C}$ for $30 \mathrm{~min}$. After 6 washings with Tween-saline, the plates were developed at room temperature for 20 min with $100 \mu \mathrm{l} /$ well of a solution of $0.2 \mathrm{mg} / \mathrm{ml}$ of $3,3^{\prime}, 5,5^{\prime}-$ tetramethylbenzidine in $0.05 \mathrm{M}$ citrate buffer $(\mathrm{pH} \mathrm{5})$ containing $0.04 \%$ hydrogen peroxide. The reaction was stopped by adding $50 \mu \mathrm{l} /$ well of $2 \mathrm{M}$ sulphuric acid. The plates were read at $450 \mathrm{~nm}$ using a Titertek Multiscan MK II. The cut-off was calculated with the accredited biood donor samples. In each assay the cut-off was 0.15 optical density units added to the average reading of the three negative control sera.

Antibodies to c100 were assayed using the OrthoHCV enzyme-linked immunoassay (Ortho Diagnostics Systems, Raritan, NJ). Positive results were confirmed in all cases by re-testing in duplicate. The secondgeneration assay from Ortho Diagnostics Systems, which includes the c100-c33 antigens (non-structural) and the c22 antigen (structural) of $\mathrm{HCV}$, was used to test 150 serum samples from NANBH and 98 samples from chronic hepatitis B.

Serological markers of $\mathrm{HBV}$ infection wcre investigated by radioimmunoassay or ELISA with commercial reagents (Ausria II, Ausab, Corab, IMx HBsAg, Ausab EIA, IMx core; Abbott Laboratories, Chicago, IL).

\section{Detection of $H C V$ sequences in serum}

Following reverse transcription of NANBH, viral sequences to cDNA amplification using the polymerase chain reaction (PCR) was performed using a tested primer technique. This assay was originally developed with primers from the NS5 region (12) and subsequently modified to improve sensitivity by the use of primers from the 5 -non-coding region of the virus (13). The 5'non-coding region primers were used in all experiments reported in this paper.

\section{Statistics}

The chi-square test and the ratio difference test were used to compare frequencies between groups. For comparison of means, Student's $t$-test was employed.

\section{Results}

All the 67 healthy blood donors studied were negative for both anti-BHC10 and anti-c100. In chronic NANBH, 
antibodies to $\mathrm{HCV}$ antigens were found more frequently with $\mathrm{BHCl} 0$ as a substrate than with $\mathrm{cl} 100(96.8 \%$ vs. $83.3 \% ; p<0.001$ ) (Fig. 1). In contrast, in chronic hepatitis $\mathrm{B}$, the prevalence of anti-BHCl0 was significantly lower than anti-c100 (18.9\% vs $29.7 \% ; p<0.001)$. Similarly in the group of miscellaneous liver diseases antiBHC10 was detected in only $4 \%$ of patients (one case of primary biliary cirrhosis who had received blood transfusions and two cases of alcoholic cirrhosis), a proportion which was significantly lower than the prevalence of anti-cl00 in this group $(11.5 \% ; p<0.001)$. In patients with hepatocellular carcinoma the frequency of positive cases for anti-BHCl0 was similar to that of anti-c100 (55.5\% vs $59.3 \% ; p=$ n.s.). In this group of patients with liver cell cancer $(n=27)$ anti-HCV antibodies were present in 18 cases, of whom 10 were negative for all serological markers of $\mathrm{HBV}$ infection.

Among the 156 patients with chronic NANBH studied, 130 cases were positive for both anti-cl00 and antiBHC10. None of the chronic NANBH patients was positive for anti-cl00 in the absence of anti-BHCl0. Twenty-six patients with chronic NANBH were negative for anti $s 100 ; 21$ of the anti-cl00 negative patients were positive for anti-BHC10. In these 21 cases we used the PCR technique to investigate the presence of $\mathrm{HCV}$ sequences in serum and we found that HCV-RNA could be detected in 19 (Table 1). PCR was also performed in 10 of the chronic NANB patients who were positive for both $\mathrm{BHCl0}$ and $\mathrm{cl} 00$ and was positive in 8 (Table 1). As mentioned, 5 cases with chronic NANBH were negative in both $\mathrm{cl00}$ and $\mathrm{BHCl0}$ assays. Of these patients one had high titres of smooth muscle antibodies and improved with steroids (suggesting autoimmunity), three were positive for both anti-HBs and anti-HBc (suggesting covert $\mathrm{HBV}$ infection), and only one had all

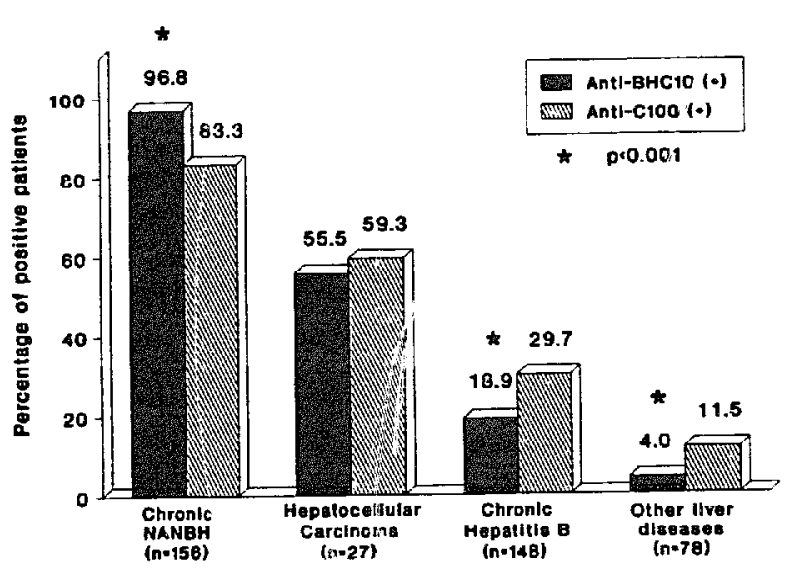

Fig. 1. Percentage of cases positive for anti-HCV using two different recombinant antigens in chronic NANBH, hepatocellular carcinoma, chronic hepatitis B and a group of miscellaneous liver diseases.
TABLE

PCR results in patients with chronic NANBH and chronic hepatitis $B$ showing different serological patterns against HCV recombinan antigens

\begin{tabular}{|c|c|c|}
\hline & $\begin{array}{l}\text { Chronic } \\
\text { NANBH } \\
(n=156)\end{array}$ & $\begin{array}{l}\text { Chronic } \\
\text { hepatitis B } \\
(n-i 48)\end{array}$ \\
\hline \multicolumn{3}{|l|}{$\begin{array}{l}\text { Group anti-BHC10 }(+) \\
\text { anti-c100(-) }\end{array}$} \\
\hline Number of patients & $2 i$ & 4 \\
\hline PCR-positive No. tested & 1921 & 04 \\
\hline \multicolumn{3}{|l|}{$\begin{array}{l}\text { Group anti-BHClO }(-), \\
\text { anti-c } 100(+)\end{array}$} \\
\hline Number of patients & 0 & 20) \\
\hline PCK-positive No. tested & - & 0.12 \\
\hline \multicolumn{3}{|l|}{$\begin{array}{l}\text { Group anti-BHClO (t), } \\
\text { anti-c } 100(+)\end{array}$} \\
\hline Number of patients & 130 & 24 \\
\hline PCR-positive No. tested & 8.10 & 310 \\
\hline
\end{tabular}

serological markers negative. Interestingly, only the latter was PCR-positive.

To see whether there was some clinical or pathological peculiarity in chronic NANBH patients with isolated positivity for anti-BHC10, we compared this subgroup $(n=21)$ with the larger population of chronic NANBH putients showing positivity for both anti-BHClO and anti-cl00 $(n=130)$. No differences between these subgroups were found in age, sex, liver histology, biochemistry or autoantibodies (Table 2). The only significant difference was a predominance of sporadic NANBH cases in the subgroup of patients with isolated positivity for anti-BHClO (Table 2).

In the patients with chronic hepatitis B, 24 subjects were positive for both anti-c100 and anti-BHClO. Twenty additional patients were positive for anti-cl00 but negative for anti-BHC10. Of these, 12 were tested by PCR for the presence of HCV-RNA in serum and all were negative. Only four patients with chronic hepatitis $\mathrm{B}$ were positive for anti-BHC10 and negative for antic100. All of these were also negative for HCV-RNA in serum (Tabie 1). However, PCR was positive in three out of ten cases with chronic hepatitis B that were positive for both $\mathrm{BHCl0}$ and cl00 (Table 1).

The $\mathrm{BHCl} 0$ assay was also compared with the secondgeneration assay from Ortho (Ortho2). In chronic NANBH $94.7 \%$ of cases were positive by both tests. However, when chronic hepatitis B was studied, more cases were positive with Ortho2 $(32.6 \%)$ than with BHCl0 (15.3\%; $p<0.001)$.

\section{Discussion}

Chronic hepatitis $\mathrm{C}$ is a common viral disease that often progresses to cirrhosis (14). The first-generation assay currently used to detect anti-HCV antibodies is 


\section{TABLE 2}

Comparison of clinical, histological, biochemical and serological features in two groups of paticnts with chronic NANBH with different anti-HCV patterns

\begin{tabular}{|c|c|c|}
\hline & \multicolumn{2}{|c|}{ Subgroups of chronic NANBH } \\
\hline & $\begin{array}{l}\text { Anti-BHCl0 } \\
(+) \\
\text { Anti-c } 100(+) \\
(n=130)\end{array}$ & $\begin{array}{l}\text { Anti-BHC10 } \\
(+) \\
\text { Anti-c100(-) } \\
(n=21)\end{array}$ \\
\hline Female & $36.1 \%$ & $23.8 \%$ \\
\hline Age (years)" & $46.2 \pm 1.2$ & $46.3 \pm 3.6$ \\
\hline No parenteral exposure & $46.5 \%$ & $85.7 \%$ \\
\hline \multicolumn{3}{|l|}{ Liver histology } \\
\hline $\mathrm{CAH}$ & $67 \%$ & $48 \%$ \\
\hline $\mathrm{CPH}$ & $10 \%$ & $19 \%$ \\
\hline Cirrhosis & $23 \%$ & $33 \%$ \\
\hline \multicolumn{3}{|l|}{ Biochemistry $_{\mathrm{a}}$} \\
\hline AST (IU 1$)$ & $97.7 \pm 8.6$ & $70.1 \pm 10.9$ \\
\hline ALT (IU/1) & $156.9 \pm 11.2$ & $111.6 \pm 14.1$ \\
\hline Alkaline phosphatase (IU/1) & $150.0 \pm 6.00$ & $151.3 \pm 8.90$ \\
\hline Albumin (g/dl) & $4.2 \pm 0.05$ & $4.3 \pm 0.12$ \\
\hline$\tau-G$ lobulin $(\mathrm{g} / \mathrm{j} \mathbf{l})$ & $1.5 \pm 0.05$ & $1.3 \pm 0.09$ \\
\hline \multicolumn{3}{|l|}{ HBV markers } \\
\hline Anti-HBs & $21.4 \%$ & $35.0 \%$ \\
\hline Anti-HBc & $29.2 \%$ & $52.6 \%$ \\
\hline \multicolumn{3}{|l|}{ Autoantibodies } \\
\hline ANA & $9.7^{\circ}$ & $4.8 \%$ \\
\hline AMA & $1.6 \%$ & $0.0^{r} ;$ \\
\hline SMA & $19.5 \%$ & $9.5 \%$ \\
\hline
\end{tabular}

"Mean \pm standard error.

${ }^{b} p<0.05$.

$\mathrm{CAH}=$ chronic active hepatitis: $\mathrm{CPH}=$ chronic persistent hepatitis.

based on the recombinant protein $\mathrm{cl} 00$ derived from the non-structural portion of the $\mathrm{HCV}$ g nome. Although the use of this assay represents an important step in the history of NANBH, recent reports have shown that it may fail to identify $\mathrm{HCV}$ infection in :ome patients (6). In our group of patients with NANBH the prevalence of anti-c100 was $83.3 \%$. This rate is similar to other European series $(2,3,5)$ which also include posttransfusional and sporadic cases. Perhaps one of the most relevant points of the present study is the finding that the test based on $\mathrm{BHClO}$, a recombinant antigen encompassing both structural and non-structural viral proteins [the core region of $\mathrm{HCV}$ (c22) and the greater part of the NS5 region], has a significantly higher sensitivity than the assay that includes only nonstructural antigens. A sensitivity similar to $\mathrm{BHC} 10$ was observed with the second-generation assay from Ortho, which also includes structural and non-structural antigens.

The prevalence of anti-HCV in chronic NANBH rose with the BHC10 assay to nearly $97 \%$ (151 out of 156 cases were positive for anti-BHC10). In the group of patients with chronic NANBH we observed that while all subjects positive for anti-c 100 were also positive for anti-BHCl0, there were 21 additional cases which were positive only for anti-BHCl0. The presence of $\mathrm{HCV}$ infection in these cases was demonstrated by the detection of HCV-RNA in 19 of them. Interestingly in the subgroup with isolated anti-BHC10 there was a significant increase in the relative number of patients without know $n$ exposure to blood products, suggesting that some sporadic cases with chronic hepatitis $\mathrm{C}$ may have a different pattern of humoral response against viral antigens.

In a recent report from Esteban et al. (16) $30 \%$ of drug addicts were negative for anti-c100 and half of these showed sustained elevation of transaminases in the absence of active HBV infection. These authors postulated the existence of chronic seronegative HCV infection or the participation of other viruses in the genesis of the liver lesion. Remarkably in our study, only five patients with chronic NANBH were seronegative for anti-BHC10, and, as mentioned, three of them were suspected of having covert hepatitis $B$ infection and one had probably autoimmune chronic hepatitis. The remaining unique seronegative patient was found to have $\mathrm{HCV}$ sequences in serum. These findings have several implications. Firstly, they indicate that $\mathrm{HCV}$ is probably the sole agent responsible for chronic NANBH, when care is taken to exclude HBV infection. Secondly, the improved sensitivity of new-generation assays will allow better indentification of HCV carriers and more efficient prevention of post-transfusional hepatitis.

One of the problems with the first-generation assay is the reported cxistence of false-positive results $(7,8)$. In the present study there is a contrast between the significantly higher frequency of anti-BHC10 in chronic NANBH and the significantly lower prevalence of this antibody in chronic hepatitis $B$ and in the miscellaneous group of liver diseases. In chronic hepatitis B all cases positive for anti-c100 but negative for anti-BHCl0 tested by PCR were negative for HCV-RNA, suggesting that these cases might be in fact false-positive results. Since the prevalence of positive cases in chronic hepatitis $B$ is comparable using $\mathrm{cl} 00$ or Ortho 2 and both assays share c100, our results suggest that there may be crossreactivity between $\mathrm{cl} 00$ and $\mathrm{HBV}$ antigens.

Finally, as reported in previous studies (16), this paper shows a high prevalence of HCV markers in hepatocellular carcinoma. The finding of anti-HCV antibodies in patients with primary liver tumors who are seronegative for $\mathrm{HBV}$ points to a significant role of $\mathrm{HCV}$ in hepatocarcinogenesis.

\section{Acknowledgements}

Supported by a grant from the Fundacion Ramón Areces, Spain and Grant No. SAL 90-0625 from CICYT, 
Spain. The authors thank Edurne Elizalde and Celia Asensio for technical assistance.

\section{References}

I Kuo G. Choo QL, Alter $\mathrm{HJ}$ et al. An assay for circulating antibodies to a major etiological virus of human non-A, non-B hepatitis. Science $1989 ; 244$ : 362-4.

2 Roggendorf $M$, Deinhardt F, Rasshofer $R$ et al. Antibodies to hepatitis C virus. Lancet 1989; ii: 324-5.

3 Chiaramonte M, Farinati F, Faguioli $S$ et al. Antibody to hepatitis $C$ virus in hepatocellular carcinoma. Lancet 1990; 335: 301-2.

4 Hopf $U$, Moller B, Kuther $D$ et al. Long term follow-up of posttransfusion and sporadic chronic hepatitis non- $A$, non-B, and frequency of circulating antibodies to hepatitis $C$ virus (HCV). J Hepatol 1989; 10: 69-76.

5 Sanchez-Tapias JM, Barrera JM, Costa J et I. Hepatitis C virus infection in patients with nonalcoholic chronic liver disease. Ann Intern Med 1990; 112: 921-4.

6 Weiner AJ, Kuo G. Bradley DW et al. Detection of hepatitis C viral sequences in non-A, non-B hepatitis. Lancet 1990;335: 1-3.

7 McFarlane IG, Smith HM, Johnson PJ, Bray GP, Vergani D, Williams R. Hepatitis $\mathbf{C}$ virus antibodies in cirrhosis active hepatitis: pathogenetic factor or false-positive result? Lancet $1990 ; 335$ : 754-7.
8 Skidmore S. Recombiant immunoblot assay for hepatils (' antibody. Lancet 1990; 335: 1346.

9 Memitove EJ. Richards WA. Destree M. Farly ISS experience with anti-HCV kit in blood donors. Lancet 1990: 336: 244-5.

10 Boudart D, Lucas JC, Muller JY, Le Carrer D, Planchon B, Harousseau JL. False-positive hepatitis $C$ virus antibody lests in paraproteinaemia. Lancet 1990; 336: 63.

II Scotto J. Hadchouel M. Herry C. Yvart J. Tiollais P. Brechot C Detection of hepatitis $B$ virus DNA in serum by a simple spot hybridization technique: comparison with results for other viral markers. Hepatology 1983; 3: 279-84.

12 Phippard D, Glazebrook J, Rodgers B, Garson JA, Briggs M, Parker D. Recombinant ELISA and PCR analysis of PTNANB serum samples. In: Proceedings of the VIII. International Congress of Virology, International Union of Microbiological Societies, Berlin, 1990; 196.

13 Garson JA, Tedder RS, Briggs $M$ et al. Detection of hepatitis $C$ viral sequences in blood donations by 'nested' polymerase chain reaction and prediction of infectivity. Lancet 1990; 335: 1419-22.

14 Garson JA, Ring C, Tuke P, Tedder RS. Enhanced detection by PCR of hepatitis C virus RNA. Lancet 1990; 336: 878-9.

15 Dienstag JL. Non-A, non-B hepatitis. l. Recognition. epidemiology. and clinical features. Gastroenterology 1983;85:439-62.

16 Esteban JI, Esteban R, Viladamiu \& et al. Hepatitis C virus antibodies among risk group in Spain. Lancet 1989; ii: 294-7.

17 Bruix J, Barrera JM, Calvet $X$ e: al. Prevalence of antibudies to hepatitis $\mathbf{C}$ virus in Spanish patients with hepatocellular carcinoma and hepatic cirrhosis. Lancet i989; ii: 1004-6. 